\title{
Pengaruh Faktor-faktor Fundamental terhadap Harga Saham pada Perusahaan Perbankan yang Terdaftar di Bursa Efek Indonesia
}

\author{
*Zakhrafi Afnan, Haryono, Susi Tri Wahyuni \\ Fakultas Ekonomi dan Bisnis Universitas Bhayangkara Surabaya, Indonesia
}

DOI: $10.46821 /$ bharanomics.v2i1.192

\begin{abstract}
Abstrak
Penelitian ini bertujuan untuk mengetahui Pengaruh Faktor - Faktor Fundamental Terhadap Harga Saham Pada Perusahaan Perbankan Yang Terdaftar Di Bursa Efek Indonesia. Penelitian ini merupakan penelitian kuantitatif dengan menggunakan data sekunder. Perusahaan yang dijadikan sampel pada penelitian ini adalah perusahaan perbankan yang terdaftar di Bursa Efek Indonesia periode tahun 2016-2018. Teknik yang digunakan adalah purposive sampling.Penelitian ini menggunakan teknik regresi data panel, uji t untuk menguji pengaruh secara parsial. Variabel bebas dalam penelitian ini terdiri dari ROE, PER, EPS, $P B V$, sedangkan untuk variable terikat yaitu Harga Saham. Hasil penelitian ini menunjukkan ROE, PER, EPS tidak berpengaruh signifikan terhadap harga saham pada perusahaan perbankan yang terdaftar di Bursa Efek Indonesia, PBV berpengaruh signifikan terhadap harga saham pada perusahaan perbankan yang terdaftar di Bursa Efek Indonesia. Diantara variabel ROE, PER, EPS, PBV, Variabel PBV yang berpengaruh dominan terhadap harga saham pada perusahaan perbankan yang terdaftar di Bursa Efek Indonesia.
\end{abstract}

Kata kunci: Harga Saham, ROE, PER, EPS, PBV.

\begin{abstract}
:
This study aims to determine the effect of fundamental factors on stock prices in banking companies listed on the Indonesia Stock Exchange. This research is a quantitative research using secondary data. The companies sampled in this study are banking companies listed on the Indonesia Stock Exchange for the period 2016 - 2018. The technique used is purposive sampling. This research uses panel data regression technique, $t$ test to partially test the effect. The independent variables in this study consisted of ROE, PER, EPS, PBV, while the dependent variable was stock prices. The results of this study indicate that ROE, PER, EPS have no significant effect on stock prices in banking companies listed on the Indonesia Stock Exchange, PBV has a significant effect on stock prices in banking companies listed on the Indonesia Stock Exchange. Among the variables ROE, PER, EPS, PBV, PBV which have a dominant effect on stock prices in banking companies listed on the Indonesia Stock Exchange.
\end{abstract}

Keywords: Stock Prices, ROE, PER, EPS, PBV.

\section{PENDAHULUAN}

Belakangan ini pasar modal merupakan pilar perekonomian suatu bangsa. pasar modal merupakan pasar untuk berbagai instrumen keuangan atau surat-surat berharga jangka panjang yang bisa diperjual belikan, baik dalam bentuk utang mapun modal sendiri. Untuk kegiatan jual beli tersebut dilakukan di Bursa Efek, yaitu sebuah pasar yang terorganisir tempat para pialang melakukan transaksi jual beli surat berharga dengan berbagai perangkat aturan yang ditetapkan Bursa Efek. Saham merupakan instrumen pasar modal yang paling banyak diminati oleh investor, karena di dalam saham sendiri menjanjikan keuntungan yang sangat besar. Menurut Darmaji dan Fakhruddin (2015), pengertian saham adalah tanda 
atau pemilikan seseorang atau badan dalam suatu perusahaan atau perseroan terbatas. Jumlah saham yang beredar di publik dan dimiliki perusahaan dipengaruhi oleh harga saham.

Pasar modal merupakan tempat atau sarana bertemunya antara penawaran dan permintaan atas instrumen keuangan jangka panjang. keberadaan pasar modal Indonesia telah menjadi perhatian besar didalam suatu bisnis. hal ini disebabkan oleh semakin meningkatnya kesadaran masyarakat untuk berinvestasi atau menjadi investor.Menurut Novita dkk., (2019) fungsi pasar modal adalah sebagai sarana untuk pengumpulan dana yang berasal dari masyarakat umum yang kemudian diinvestasikan di pasar modal yang memiliki tujuan untuk mencari keuntungan yang akan berguna untuk memajukan perusahaannya dan membantu mendukung perekonomian suatu negara.

Menurut Wira (2014:3) biasanya analisis fundamental digunakan untuk mengetahui valuasi saham, berapa nominal rupiah saham itu layak dihargai. pada prinsipnya analisis fundamental digunakan untuk mengetahui apakah suatu saham overvalued (mahal) atau undervalued (murah).Menurut Darmadji dan Fakhruddin (2015), analisis fundamental merupakan salah satu cara untuk melakukan penilaian saham dengan mempelajari atau mengamati berbagai indikator yang terkait dengan kondisi makro ekonomi dan kondisi industri suatu perusahaan hingga berbagai indikator keuangan dan manajemen perusahaan.

Analisis fundamental merupakan analisis yang mencoba memperkirakan harga saham di masa yang akan datang dengan cara mengestimasi nilai faktor fundamental yang mempengaruhi harga. Analisis fundamental juga disebut analisis perusahaan karena menggunakan data keuangan perusahaan dalam menghitung nilai intrinsik saham. teknik analisis yang sering digunakan para investor untuk menganalisis laporan keuangan yaitu dengan menggunakan analisis fundamental yang tertuju pada analisis rasio keuangan perusahaan.

Pada tahap analisis terhadap perusahaan dalam pendekatan fundamental, kinerja keuangan menjadi salah aspek penilaian yang harus diperhatikan. Investor dapat mengukur kinerja keuangan perusahaan menggunakan analisis rasio keuangan. Pada umumnya perusahaan memerlukan modal untuk memenuhi kebutuhan operasional, kegiatan perusahaannya dan kebutuhan investasi jangka panjang perusahaan.

\section{TINJAUAN PUSTAKA \\ Return on Equity (ROE)}

Menurut Sudana (2011:22) Return on Equity (ROE) adalah kemampuan perusahaan untuk menghasilkan laba setelah pajak dengan menggunakan modal sendiri yang dimiliki perusahaan. Semakin tinggi rasio ini maka semakin efisien penggunaan modal sendiri yang dilakukan oleh pihak manajemen perusahaan. Apabila laba yang dihasilkan semakin banyak maka investor memperoleh keuntungan yang semakin besar atas investasi yang dilakukannya. Semakin besar rasio ini maka menunjukkan semakin efisien perusahaan mengelola dengan modal yang sendiri yang dimiliki perusahaan.

Menurut Herry (2017:194 ) hasil pengembalian atas ekuitas Return On Equity (ROE) merupakan rasio yang menunjukkan seberapa besar kontribusi ekuitas dalam menciptakan laba bersih. Dengan kata lain rasio ini digunakan untuk mengukur seberapa besar jumlah laba bersih yang akan dihasilkan dari 
setiap rupiah dana yang tertanam dalam total ekuitas. Rasio ini dihitung dengan membagi laba bersih terhadap ekuitas.

\section{Price Earning Ratio (PER)}

Menurut Herry (2017), Price Earning Ratio (PER) merupakan rasio yang menunjukkan hasil perbandingan antara harga pasar per lembar saham dengan laba per lembar saham. Lewat rasio ini, harga saham sebuah emiten dibandingkan dengan laba bersih yang dihasilkan oleh emiten tersebut dalam setahun. Dengan mengetahui besaran Price Earning Ratio (PER) tersebut, calon investor potensial dapat mengetahui apakah harga sebuah saham tergolong wajar atau tidak (secara nyata) sesuai kondisi saat ini dan bukannya berdasarkan pada perkiraan di masa mendatang.

Menurut Atkinson (2012) Rasio harga laba Price Earning Ratio (PER) adalah rasio harga pasar terhadap laba per lembar saham, merupakan pengukuran yang banyak dikutip oleh statistik pasar. Menurut Hani (2015) Price Earning Ratio (PER) merupakan rasio yang menunjukkan berapa besar keuntungan yang diperoleh investor atau pemegang saham per saham. Menurut Noor (2014) Price Earning Ratio (PER) merupakan rasio yang menunjukkan antara harga saham (market value) dengan laba per saham (Earning Per Share). Rasio ini menunjukkan kemampuan perusahaan mendapat laba. Makin besar rasio, makin besar pula kemampuan perusahaan mendapat laba, dan ini mengindikasikan prospeknya makin baik, dan sebaliknya.

\section{Earning per share (EPS)}

Menurut Fahmi (2017:96) pengertian Earning Per Share (EPS) adalah bentuk pemberian keuntungan yang diberikan kepada para pemegang saham dari setiap lembar saham yang dimiliki. Earning per share (EPS) merupakan salah satu rasio keuangan yang sering digunakan oleh investor untuk menganalisa kemampuan perusahaan menghasilkan laba, sehingga semakin besar Earning Per Share (EPS) maka investor akan tertarik untuk melakukan investasi pada perusahaan tersebut. Menurut Darmadji dan Fakhruddin (2015:154) Laba per saham atau Earning Per Share (EPS) merupakan rasio yang menunjukkan bagian laba untuk setiap saham. Earning Per Share (EPS) menggambarkan profitabilitas perusahaan yang tergambar pada setiap lembar saham. Makin tinggi nilai Earning Per Share(EPS) tentu saja menggembirakan pemegang saham karena makin besar laba yang disediakan untuk pemegang saham dan kemungkinan peningkatan jumlah dividen yang diterima pemegang saham. 


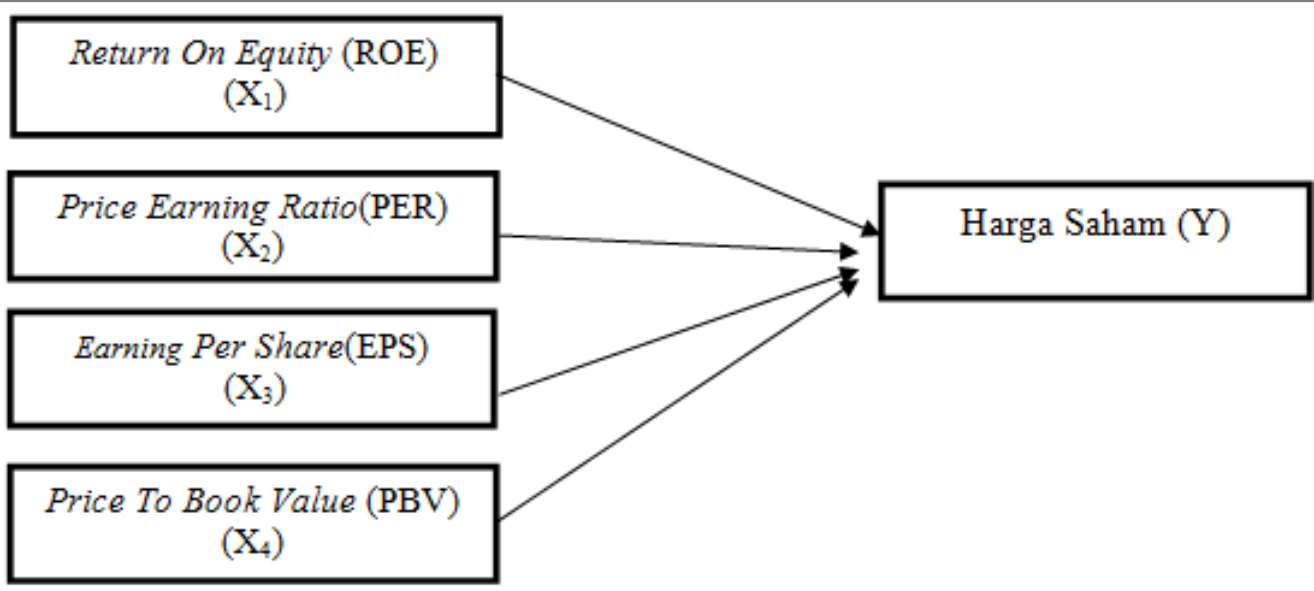

Gambar 1

Kerangka Konseptual

\section{Price To Book Value (PBV)}

Menurut Hani (2015) Price To Book Value (PBV) merupakan hubungan antara harga saham dan nilai buku per lembar saham. Price To Book Value (PBV) digunakan untuk melihat ketidak wajaran harga saham. Price To Book Value (PBV) yang rendah menunjukkan harga sahamnya murah, jika posisi harga saham berada dibawah book value ada kecenderungan harga saham tersebut akan menuju keseimbangan minimal sama dengan nilai bukunya. Rasio ini bisa juga dipakai sebagai pendekatan alternatif untuk menentukan nilai suatu saham karena secara teoritis nilai pasar suatu saham haruslah mencerminkan nilai bukunya.

Menurut Atkinson (2012) Price To Book Value (PBV) adalah menghitung nilai yang diberikan oleh pasar kepada organisasi sebagai proporsi dari asset yang diukurnya.Menurut Purwanto dan Sumarto (2017), Price To Book Value (PBV) adalah perbandingan antara harga saham di pasar dengan nilai buku perusahaan tersebut.

\section{Hipotesis}

Hipotesis adalah jawaban sementara dari penelitian yang diajukan, yang masih harus diuji kembali secara empiris yaitu :

a. Bahwa Return On Equity (ROE) berpengaruh secara signifikan terhadap harga saham pada perusahaam perbankan yang terdaftar di Bursa Efek Indonesia.

b. Bahwa Price Earning Ratio (PER) berpengaruh secara signifikan terhadap harga saham pada perusahaam perbankan yang terdaftar di Bursa Efek Indonesia.

c. Bahwa Earning Per Share (EPS) berpengaruh secara signifikan terhadap harga saham pada perusahaam perbankan yang terdaftar di Bursa Efek Indonesia.

d. Bahwa Price to Book Value (PBV) berpengaruh secara signifikan terhadap harga saham pada perusahaam perbankan yang terdaftar di Bursa Efek Indonesia. 
e. Bahwa Return On Equity (ROE),Price Earning Ratio (PER), Earning Per Share (EPS), Price to Book Value (PBV) berpengaruh dominan terhadap harga saham pada perusahaam perbankan yang terdaftar di Bursa Efek Indonesia.

\section{METODE PENELITIAN}

Sugiyono (2018:131) mengemukakan bahwa sampel adalah bagian dari jumlah dan karakteristik yang dimiliki oleh populasi tersebut. Pada penelitian ini, teknik pengambilan sampel menggunakan metode purposive sampling. Lokasi objek penelitian adalah perusahaan perbankan yang terdaftar di bursa efek Indonesia yang di akses melalui website idx www.idx.com. waktu penelitian dilakukan pada tahun 2021.

Pengumpulan data dalam penelitian menggunakan metode dokumentasi. Dokumentasi digunakan dalam mengumpulkan data sekunder berupa laporan keuangan pada saham perusahaan perbankan pada tahun 2016 - 2018. Data di peroleh dari website resmi Bursa Efek Indonesia (www.idx.co.id). Data yang digunakan dalam penelitian ini adalah data sekunder. Menurut Sugiyono (2018) data sekunder merupakan data yang tidak langsung memberikan data kepada pengumpul data, misalnya lewat orang lain atau lewat dokumen. Penelitian ini mengambil data laporan keuangan tahun 2016- 2018. Data diperoleh dari website resmi Bursa Efek Indonesia (www.idx.co.id). Sumber data yang digunakan dalam penelitian ini diperoleh dari website resmi bursa efek Indonesia (www.idx.com). Data dalam penelitian ini adalah laporan keuangan pada saham perusahaan perbankan tahun 2016 - 2018.

Pengujian Data menggunakanCommon Effect Model (CEM) merupakan pendekatan yang paling sederhana dengan mengabaikan dimensi cross section dan time series. Model Common Effect Model (CEM) mengasumsikan bahwa intersep masing-masing variabel adalah sama, begitu juga dengan koefisien slop untuk semua unit time series dan cros section. Fixed Effect Model dibagi menjadi dua asumsi, yakni slope konstan, namun terdapat variasi intersep antar individu atau disebut sebagai Model Efek Individu. Pendekatan Random Effect Model melibatkan korelasi antar error terms karena berubahnya waktu maupun unit observasi.

Pemilihan model menggunakan Uji Chow Memilih antara Common Effect Model (CEM) dan Fixed Effect Model (FEM). Uji Hausman dapat digunakan untuk memilih antara Fixed Effect Model dan Random Effect Model. Uji Lagrange Multiplier merupakan uji signifikansi Random Effect Model yang dilakukan untuk menentukan apakah model dengan pendekatan Random Effect Model lebih baik digunakan dari pada model Common Effect Model. Uji normalitas merupakan pengujian terhadap kenormalan distribusi data. Jika suatu residual model tidak terdistribusi normal, maka uji t kurang relevan digunakan untuk menguji koefisien regresi. Uji tdigunakan untuk mengetahui pengaruh masing-masing variabel bebas terhadap variabel terikat (Ghozali, 2018:179). Jika nilai signifikansi lebih kecil atau kurang dari $(\boldsymbol{\alpha})$ 0,05 dan thitung $>\mathrm{t}$ tabel, maka $\mathrm{H}_{0}$ ditolak dan $\mathrm{H}_{1}$ diterima. Hal ini berarti bahwa secara parsial variabel bebas berpengaruh signifikan terhadap variabel terikat. Jika nilai signifikansi lebih besar dari 0,05 dan $\mathrm{t}$ hitung < $\mathrm{t}$ tabel, maka $\mathrm{H}_{0}$ diterima dan $\mathrm{H}_{1}$ ditolak. Hal ini 
berarti bahwa secara parsial variabel bebas tidak berpengaruh signifikan terhadap variabel terikat.

\section{HASIL DAN PEMBAHASAN}

\section{Uji Normalitas}

Dari tabel 1, nilai distribusi statistik dari chi-square sebesar 111.325822 dengan probabilitas $0.0000<0.05$, maka $\mathrm{H}_{0}$ ditolak dan $\mathrm{H}_{1}$ diterima, jadi model yang tepat digunakan adalah model Fixed Effect.

Dari Tabel 2 di atas, nilai probabilitas Cross-section random adalah $0.0000<0.05$ maka $\mathrm{H}_{0}$ ditolak dan $\mathrm{H}_{1}$ diterima. Jadi model yang tepat digunakan adalah model fixed effect.

Dari tabel 3, nilai Both Breusch-Pagan adalah $0.0031<0.05$ maka $\mathrm{H}_{0}$ ditolak dan $\mathrm{H}_{1}$ diterima. Jadi model yang tepat digunakan adalah model Random Effect.

Tabel 1

Hasil Uji Chow

Redundant Fixed Effects Tests

Equation: Untitled

Test cross-section fixed effects

\begin{tabular}{llll}
\hline Effects Test & Statistic & d.f. & Prob. \\
\hline Cross-section F & 10.221062 & $(19,36)$ & 0.0000 \\
Cross-section Chi-square & 111.325822 & 19 & 0.0000 \\
\hline
\end{tabular}

Sumber: Data Diolah

Tabel 2

Hasil Uji Hausman

Correlated Random Effects - Hausman Test

Equation: Untitled

Test cross-section random effects

\begin{tabular}{llll}
\hline Test Summary & Chi-Sq. & & \\
Cross-section random & Statistic & Chi-Sq. d.f. & Prob. \\
\hline Sumber & 32.104303 & 4 & 0.0000 \\
\hline
\end{tabular}

Sumber: Data Diolah

Tabel 3

Hasil Uji Langrange Multiplier

Lagrange Multiplier Tests for Random Effects

Null hypotheses: No effects

Alternative hypotheses: Two-sided (Breusch-Pagan) and one-sided

(all others) alternatives

\begin{tabular}{|c|c|c|c|}
\hline & \multicolumn{3}{|c|}{ Test Hypothesis } \\
\hline & Cross-section & Time & Both \\
\hline Breusch-Pagan & $\begin{array}{l}8.645881 \\
(0.0033)\end{array}$ & $\begin{array}{l}0.106121 \\
(0.7446)\end{array}$ & $\begin{array}{l}8.752002 \\
(0.0031)\end{array}$ \\
\hline
\end{tabular}

Sumber: Data Diolah 


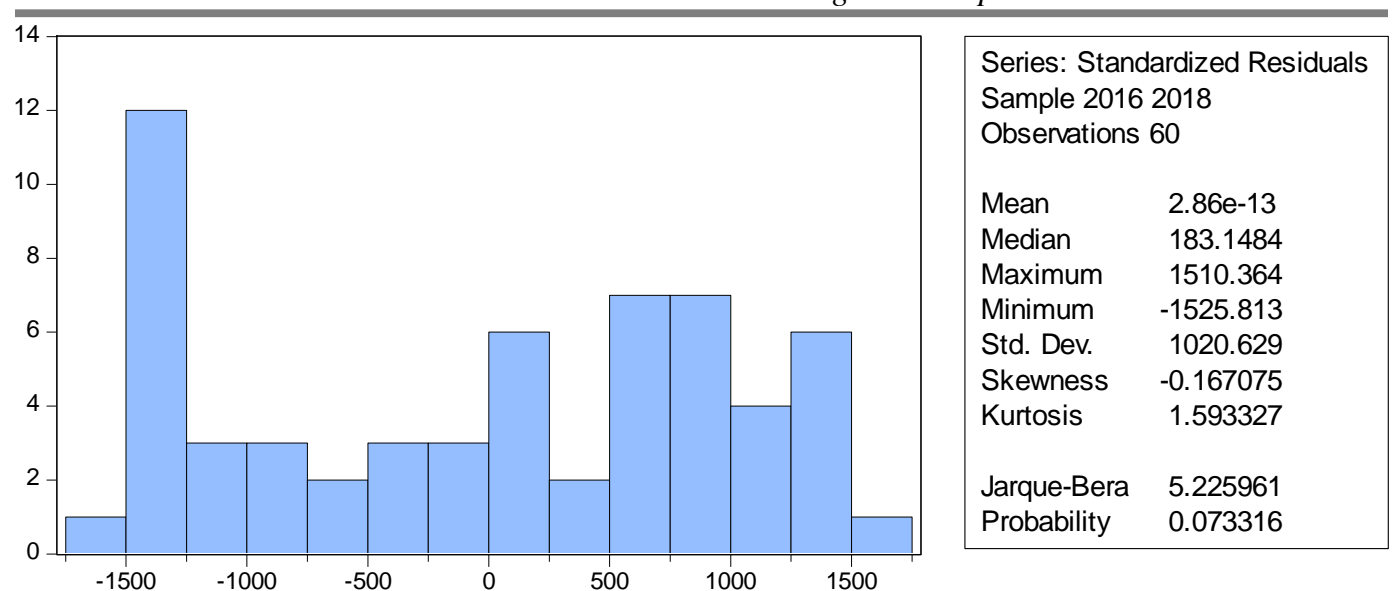

Gambar 1

Hasil Uji Normalitas

Sumber : Eviews 9

\section{Uji Normalitas}

Berdasarkan hasil uji normalitas gambar 1 diatas diketahui bahwa hasil probability $0.073316>0.05$ maka dapat disimpulkan bahwa residual berdistribusi normal.

\section{Uji Signifikansi}

Berdasarkan uji chow, uji hausman dan langrange multipier, model yang terpilih adalah model Fixed Effect. Maka selanjutnya dilakukan uji signifikansi dari model yang terpilih.

\section{Uji t}

Berikut ini adalah uji t dari masing variabel bebas terhadap variabel terikat :

Variabel Return On Equity (ROE)

Berdasarkan hasil output pada tabel 4 didapat variabel bebas Return On Equity (ROE) sebesar -0.450863 dengan nilai probabilitas sebesar $0.6548>$ 0.05 maka $\mathrm{H}_{0}$ diterima dan $\mathrm{H}_{1}$ ditolak artinya variabel Return On Equity (ROE) tidak berpengaruh secara signifikan terhadap harga saham.

\section{Variabel Price Earning Ratio (PER)}

Berdasarkan hasil output pada tabel 4 didapat variabel bebas Price Earning Ratio (PER) sebesar 0.426549 dengan nilai probabilitas sebesar $0.6722>$ 0.05 maka $\mathrm{H}_{0}$ diterima dan $\mathrm{H}_{1}$ ditolak artinya variabel Price Earning Ratio (PER) tidak berpengaruh secara signifikan terhadap harga saham.

\section{Variabel Earning Per Share (EPS)}

Berdasarkan hasil output pada tabel 4 didapat variabel bebas Earning Per Share (EPS) sebesar 0.263169 dengan nilai probabilitas sebesar 0.7939>0.05 maka $\mathrm{H}_{0}$ diterima dan $\mathrm{H}_{1}$ ditolak artinya variabel Earning Per Share (EPS) tidak berpengaruh secara signifikan terhadap harga saham. 


\section{Tabel 4}

Hasil Model Fixed Effect

\begin{tabular}{|c|c|c|c|c|}
\hline \multicolumn{5}{|l|}{ Dependent Variable: Y } \\
\hline \multicolumn{5}{|c|}{ Method: Panel Least Squares } \\
\hline \multicolumn{5}{|c|}{ Date: 06/02/21 Time: 09:50 } \\
\hline \multicolumn{5}{|c|}{ Sample: 20162018} \\
\hline \multicolumn{5}{|l|}{ Periods included: 3} \\
\hline \multicolumn{5}{|c|}{ Cross-sections included: 20} \\
\hline \multicolumn{5}{|c|}{ Total panel (balanced) observations: 60} \\
\hline Variable & Coefficient & Std. Error & t-Statistic & Prob. \\
\hline $\mathrm{C}$ & 512.8136 & 820.9344 & 0.624671 & 0.5361 \\
\hline $\mathrm{X} 1$ & -15.62592 & 34.65782 & -0.450863 & 0.6548 \\
\hline $\mathrm{X} 2$ & 3.707373 & 8.691557 & 0.426549 & 0.6722 \\
\hline $\mathrm{X} 3$ & 0.466094 & 1.771086 & 0.263169 & 0.7939 \\
\hline $\mathrm{X} 4$ & 1601.377 & 419.2982 & 3.819184 & 0.0005 \\
\hline \multicolumn{5}{|c|}{ Effects Specification } \\
\hline \multicolumn{5}{|c|}{ Cross-section fixed (dummy variables) } \\
\hline R-squared & 0.953121 & Mean de & ident var & 3346.817 \\
\hline Adjusted R-squared & 0.923170 & S.D. dep & dent var & 4921.832 \\
\hline S.E. of regression & 1364.242 & Akaike i & criterion & 17.56376 \\
\hline Sum squared resid & 67001658 & Schwarz & terion & 18.40150 \\
\hline Log likelihood & -502.9128 & Hannan- & inn criter. & 17.89145 \\
\hline F-statistic & 31.82311 & Durbin- & tson stat & 1.716927 \\
\hline Prob(F-statistic) & 0.000000 & & & \\
\hline
\end{tabular}

Sumber: Eviews 9

\section{Variabel Price To Book Value (PBV)}

Berdasarkan hasil output pada tabel 4 didapat variabel bebas Price To Book Value (PBV) sebesar 3.819184 dengan nilai probabilitas sebesar $0.0005<$ 0.05 maka $\mathrm{H}_{0}$ ditolak dan $\mathrm{H}_{1}$ diterima artinya variabel Price To Book Value (PBV)berpengaruh secara signifikan terhadap harga saham.

\section{Pembahasan}

Hasil dari penelitian variabel Return On Equity (ROE) memiliki nilai probabilitas $0.6548>0.05$. maka dapat disimpulkan Return On Equity (ROE) tidak berpengaruh secara signifikan terhadap harga saham. Seharusnya berdasarkan teori signal, semakin tingginya nilaiReturn On Equity(ROE) akan mendorong para invetor untuk bahwa perusahaan mampu menghasilkan profitabilitas yang baik. Namun dalam pengujian yang dilakukan ROE tidak memiliki pengaruh yang signifikan terhadap harga saham.

Hasil dari penelitian variabel Price Earning Ratio (PER) memiliki nilai probabilitas $0.6722>0.05$. maka dapat disimpulkan Price Earning Ratio (PER) tidak berpengaruh secara signifikan terhadap harga saham. Dengan hasil penelitian ini adanya PER belum mampu mempengaruhi minat investor dalam keputusan menanamkan saham pada perusahaan, investor harus melihat faktor lain yang lebih berpengaruh untuk menanamkan sahamnya sehingga tidak berpengaruh terhadap harga saham. 
Hasil dari penelitian variabel Earning Per Share (EPS) memiliki nilai probabilitas $0.7939>0.05$. maka dapat disimpulkan Earning Per Share (EPS) tidak berpengaruh secara signifikan terhadap harga saham. Tidak adanya pengaruh yang signifikan disebabkan karena laba bersih yang dihasilkan tidak sebanding dengan jumlah lembar saham yang akan di bagikan kepada pemegang saham. Sehingga akan mengurangi minat investor untuk berinvestasi dan mengakibatkan turunnya harga saham perbankan yang terdaftar di Bursa Efek Indonesia (Ekawati dan Yuniarti 2020).

Hasil dari penelitian variabel Price To Book Value (PBV) memiliki nilai probabilitas $0.0005<0.05$. maka dapat disimpulkan Price To Book Value (PBV) berpengaruh secara signifikan terhadap harga saham. Price To Book Value (PBV) mencerminkan tingkat keberhasilan manajemen perusahaan dalam menjalankan perusahaan, mengelola sumber daya yang tercermin pada harga saham pada akhir tahun.

Berdasarkan hasil penelitian menyatakan bahwa variabel Price To Book Value (PBV) berpengaruh dominan terhadap harga saham karena variabel Price To Book Value (PBV) memiliki nilai koefisien tertinggi sebesar 1601.377 dan nilai probabilitas rendah sebesar 0.0005 dibandingkan variabel bebas lainnya dan berpengaruh terhadap harga saham. Price To Book Value (PBV) mencerminkan tingkat keberhasilan manajemen perusahaan dalam menjalankan perusahaan, mengelola sumber daya yang tercermin pada harga saham pada akhir tahun.

\section{SIMPULAN}

Return On Equity (ROE), Price Earning Ratio (PER), Earning Per Share (EPS) tidak berpengaruh secara signifikan terhadap harga saham pada perusahaan perbankan yang terdaftar di Bursa Efek Indonesia. Price To Book Value (PBV) berpengaruh secara signifikan terhadap harga saham pada perusahaan perbankan yang terdaftar di Bursa Efek Indonesia. Diantara variabel Return On Equity (ROE), Price Earning Ratio (PER), Earning Per Share (EPS), Price To Book Value (PBV) yang berpengaruh dominan terhadap harga saham adalah variabel Price To Book Value (PBV).

\section{DAFTAR PUSTAKA}

Atkinson, 2012, Akuntansi Manajemen, Ed. 5, Cet. 1. Jakarta: Permata Duri Media.

Darmadji, Tjiptono dan Fakhruddin, Hendy. 2015, Pasar Modal di Indonesia, Salemba Empat, cetakan ketiga, Jakarta.

Fahmi, Irham. 2017, Pengantar Pasar Modal. Cetakan ketiga. Bandung Alfabeta.

Hani. 2015, Analisis Laporan Keuangan. Medan: Umsu Press.

Herry. 2017,Manajemen Investasi. Bandung: Pustaka Setia.

Ivan. 2018, Analisis Pengaruh Faktor-Faktor Fundamental Terhadap Harga Saham (Studi Empiris Pada Perusahaan Manufaktur Yang Terdaftar di Bursa Efek Indonesia Periode 2012 - 2015) Jurnal Muara Ilmu Ekonomi dan Bisnis Vol. 2, No. 1, April 2018 
Noor. 2014, Investasi, Pengelolaan Keuangan, dan Pengembangan Ekonomi Masyarakat. Edisi. 1. Jakarta: Mitra Wacana Media.

Novita, Firnanda, Inesella, Maureen dan Kaluge, David. 2019, Analisis Pengaruh Faktor-Faktor Fundamental terhadap Harga Saham pada Bank - Bank Plat Merah tahun 2008-2018.Jurnal Akuntansi Keuangan dan Perpajakan Indonesia Vol : 7, no 2, 2019

Nurhadi, Elan dan Pranyoto, Suhari. 2019, Pengaruh Earning Per Share (EPS), Price Earning Ratio (PER) Dan Price Book Value (PBV) Terhadap Harga Saham Emiten Perbankan Indeks LQ45 Di Bursa Efek Indonesia Tahun 2013 - 2017Aliansi Perguruan Tinggi (APERTI) BUMN Vol, 1, Agustus 2019

Purwanto dan Sumarto. (2017). Manajemen Investasi. Ed. 1. Jakarta: Mitra Wacana Media.

Sari, Maya, dan Jufrizen. 2019, Pengaruh Price Earning Ratio Dan Return On Asset Terhadap Price To Book Value, Jurnal Krisna: Kumpulan Riset Akuntansi; Vol. 10, No. 2 Januari 2019

Sugiyono. 2018. Metode Penelitian Kuantitatif. Bandung: Alfabeta.

Sudana, I Made. 2011. Manajemen Keuangan Perusahaan Teori \& Praktik. Jakarta: Erlangga.

Wira, Desmond. 2014. Buku Wajib Investor Saham : Analisis Fundamental Saham. Jakarta : Exceed. 